$$
\text { CONF-9605196-1 }
$$

UCRL-JC-122097

PREPRINT

\title{
Summary of Personal Monitoring Data for Asbestos-Related Maintenance Work at the Lawrence Livermore National Laboratory
}

\author{
S.M. Franaszek \\ R.J. Kelly
}

This paper was prepared for submittal to the American Industrial Hygiene Conference and Exposition

Washington, $D C$

May 19-24, 1996
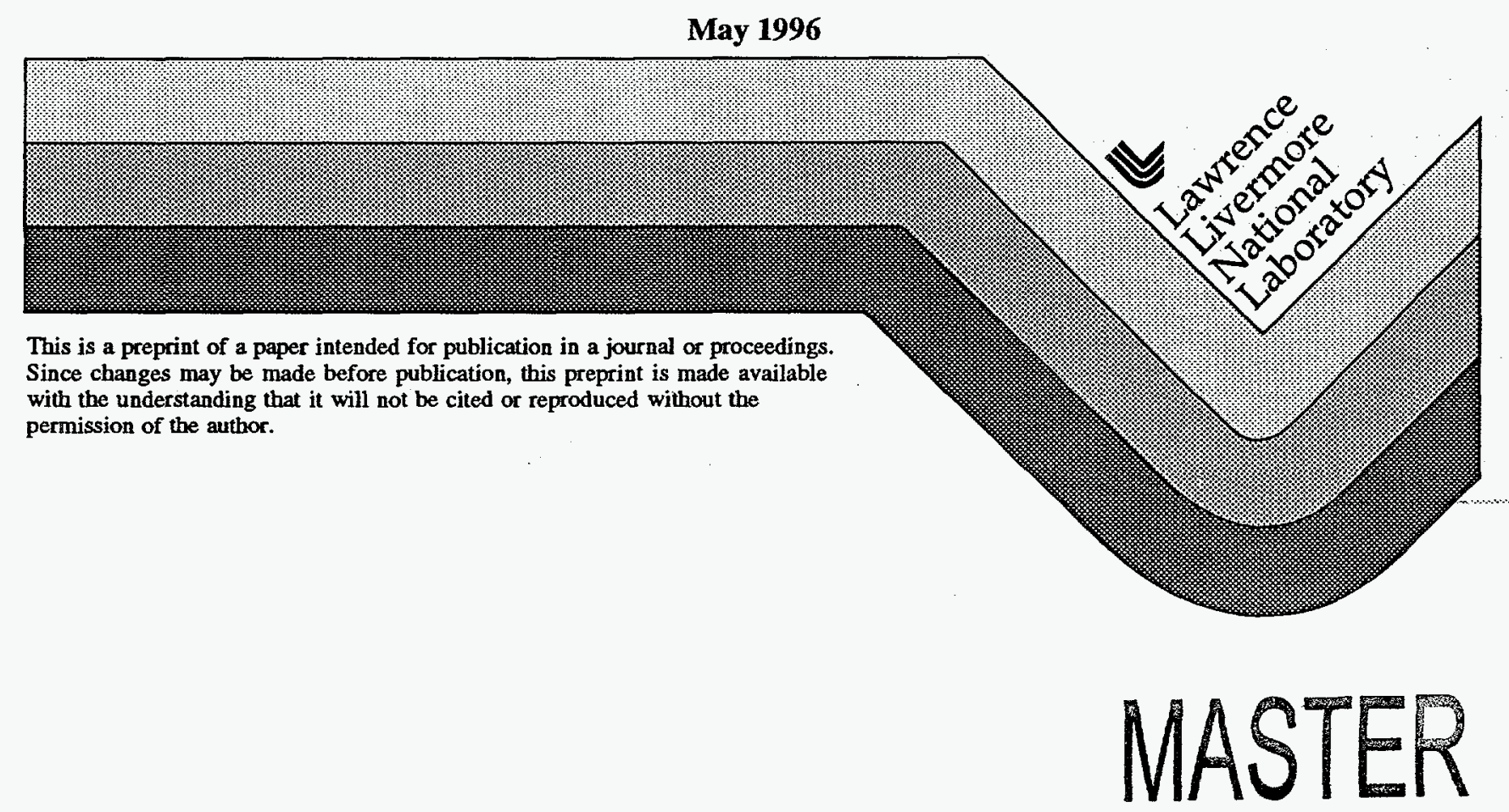
This document was prepared as an account of work sponsored by an agency of the United States Government. Neither the United States Government nor the University of California nor any of their employees, makes any warranty, express or implied, or assumes any legal liability or responsibility for the accuracy, completeness, or usefulness of any information, apparatus, product, or process disclosed, or represents that its use would not infringe privately owned rights. Reference herein to any specific commercial product, process, or service by trade name, trademark, manufacturer, or otherwise, does not necessarily constitute or imply its endorsement, recommendation, or favoring by the United States Government or the University of California. The views and opinions of authors expressed herein do not necessarily state or reflect those of the United States Government or the University of California, and shall not be used for advertising or product endorsement purposes. 


\section{DISCLAIMER}

Portions of this document may be illegible in electronic image products. Images are produced from the best available original document. 
SUMMARY OF PERSONAL MONITORING DATA FOR ASBESTOS-RELATED MAINTENANCE WORK AT THE LAWRENCE LIVERMORE NATIONAL LABORATORY S. M. Franaszek, R. J. Kelly, Hazards Control Department,

Lawrence Livermore National Laboratory, Livermore, CA 94551 
solvents, , transite (cement asbestos ) work, and roofing material removal. Data ranges and mean values were calculated for all procedure description categories. These results are presented in both chart and graph form. These charts are a historical record of exposure during 


\section{0-Minute Excursion Limit (EL) Samples}

- $\quad 77$ of the 186 reported results were 30-minute EL values.

- None of the results exceeded the 30 minute excursion limit of $1.0 \mathrm{f} / \mathrm{cc}$.

- Eight excursion sample results (9\%). approached the 30-minute Excursion Limit ( $>0.33 \mathrm{f} / \mathrm{cc}$ or $33 \%$ of the applicable EL) .

- Seven of the eight samples that approached the 30 Minute Excursion Limit were in the TSI removal with Glove Bag procedure description category.

- One of the samples that approached the 30 minute EL was in the Decontamination operation category.

Summary of 30 minute Excursion Limit Sample Results

\begin{tabular}{|c|c|c|c|c|c|}
\hline Work Category & \# Samples & $\begin{array}{l}\text { Approachin } \\
\text { EL }\end{array}$ & $\begin{array}{l}\text { \# Greater } \\
\text { than EL }\end{array}$ & $\begin{array}{l}\text { Mean } \\
\text { (f/cc) }\end{array}$ & $\begin{array}{l}\text { Range } \\
\text { (f/cc) }\end{array}$ \\
\hline decontamination & 3 & 1 & 0 & 0.14 & $0.04-0.36$ \\
\hline TSI/glove bag & $\overline{25}$ & 7 & 0 & 0.30 & $0.05-0.91$ \\
\hline misc. gasket/insul & 6 & 1 & 0 & 0.21 & $0.09-0.53$ \\
\hline wallboard & $\overline{7}$ & 0 & 0 & 0.05 & $0.04-0 . \overline{09}$ \\
\hline VAT removal & $\overline{13}$ & 0 & 0 & 0.04 & $0.04-0.06$ \\
\hline mastic removal & 6 & 0 & 0 & 0.05 & $0.04-0.06$ \\
\hline transite work & 6 & 0 & 0 & 0.05 & $0.02-0.06$ \\
\hline roofing work & 4 & 0 & 0 & 0.03 & $0.00-0.04$ \\
\hline
\end{tabular}




\section{CONCLUSIONS}

- Work procedures which rarely resulted in significant exposures included wallboard/skimcoat removal, vinyl asbestos tile (VAT) abatement using wet methods; the removal of VAT mastic using solvents, , Transite (cement asbestos ) work, and roofing material removal

- Work procedures which frequently resulted in the exposures that approached or exceeded regulatory limits included Glove Bag removal of TSI, Surface Decontamination, and gasket and wire insulation removal.

- Glove bag removal of TSI resulted in significant exposures. 7 of $25(28 \%)$ reported EL samples approached the regulatory limit of $1.0 \mathrm{f} / \mathrm{cc} .3$ of 22 $(14 \%)$ reported 8-hour TWA's approached the PEL of $0.1 \mathrm{f} / \mathrm{cc}$. The short duration of most glove bag jobs limited 8-hour TWA exposures.

- Surface decontamination resulted in significant exposures. 1 of 3 (33\%) reported 30 minute EL samples approached the applicable regulatory limit of $11.0 \mathrm{f} / \mathrm{cc}$. 1 of the $28(4 \%)$ reported TWA results exceeded the applicable regulatory limit of $0.1 \mathrm{f} / \mathrm{cc} .8(28 \%)$ of the reported TWA results approached 0.1 $\mathrm{f} / \mathrm{cc}$

- Work procedures where exposures frequently approached or exceeded regulatory limits typically involved working with materials that contain high percentage asbestos in a loose matrix.

- Work procedures where exposures were well below regulatory limits frequently involved working with asbestos containing materials in a tightly bound matrix.

This work was performed under the auspices of the U.S. Dept. of Energy at LLNL under contract no. W-7405-Eng-48. 
